Note

\section{Vulculic Acid, a Pollen Germination Inhibitor Produced by the Fungus, Penicillium sp.}

\author{
Yasuo Kimura, Masahiko Nishibe, \\ Hiromitsu NaKaJima and Takashi Hamasaki \\ Department of Bioresource Science, \\ Tottori University, Koyama, \\ Tottori 680, Japan \\ Received September 7, 1990
}

In the course of our search for pollen germination inhibitors among fungal metabolites, according to the bioassay method ${ }^{1}$ that uses pollen grains of Pinus thunbergii Parl, we found the presence of an inhibitor in the culture filtrate of Penicillium sp. (F-25) After isolating an active compound designated vulculic acid (1), we now report the structural elucidation of 1 , as well as biological activity of $\mathbf{1}$ and its derivatives $(\mathbf{2}, \mathbf{3})$.

The fungus used, Penicillium sp. (F-25), was cultured stationarily in a malt extract medium containing $3 \%$ peptone at $24^{\circ} \mathrm{C}$ for 21 days. The culture broth (10 l) was filtered, and the filtrate was adjusted to $\mathrm{pH} 2.0$ with dil. $\mathrm{HCl}$. Subsequently, the filtrate was extracted with ethyl acetate, and evaporation of the solvent gave a brown mush, which was chromatographed on a silica gel column eluting with benzene-ethyl acetate. The active fractions were then applied on a Sephadex LH-20 column, eluting with chloroform-methanol $(2: 1, \mathrm{v} / \mathrm{v})$, and 1 was finally obtained as colorless needles ( $38 \mathrm{mg}$ ) by crystallizing from benzene-ethyl acetate.<smiles>[R]OC(=O)Cc1cc(OC)c(O)c(O)c1[R]</smiles>

$$
\begin{array}{ll}
1 & R_{1}=\stackrel{9}{\mathrm{COCH}} \mathrm{H}_{3}, \mathrm{R}_{2}=\mathrm{H} \\
2 & \mathrm{R}_{1}=\mathrm{COCH}_{3}, \mathrm{R}_{2}=\mathrm{CH}_{3} \\
3 & R_{1}=\mathrm{R}_{2}=\mathrm{H}
\end{array}
$$

1 had following physicochemical properties: $\mathrm{mp}$ 144-145 ${ }^{\circ}$; HR-EIMS $m / z: 240.0664\left(\mathrm{M}^{+}, 240.0634\right.$, calcd. for $\mathrm{C}_{11} \mathrm{H}_{12} \mathrm{O}_{6}$ ); UV $\lambda_{\max }(\mathrm{EtOH}) \mathrm{nm}(\varepsilon): 205(11,700), 234$ (sh, 7600), 287 (4700); IR $v_{\max }(\mathrm{KBr}) \mathrm{cm}^{-1}: 3410,1720$, $1630,1610,1580,1500,1420,1345,1280,1160,1110$. The NMR data are shown in Table I. The UV data suggested that it was a substituted phenol which was positive to alcoholic ferric chloride. The IR and ${ }^{1} \mathrm{H}-$ and ${ }^{13} \mathrm{C}-\mathrm{NMR}$ spectra of 1 indicated the presence of a carboxymethyl group $\left[1720 \mathrm{~cm}^{-1}, \delta_{\mathrm{H}} 3.64(2 \mathrm{H}, \mathrm{s}), \delta_{\mathrm{C}} 40.9, \delta_{\mathrm{C}} 176.5\right]$, an acetyl group $\left[1630 \mathrm{~cm}^{-1}, \delta_{\mathrm{H}} 2.55(3 \mathrm{H}, \mathrm{s}), \delta_{\mathrm{C}} 33.1, \delta_{\mathrm{C}} 207.2\right]$, a methoxyl group $\left[\delta_{\mathrm{H}} 3.86(3 \mathrm{H}, \mathrm{s}), \delta_{\mathrm{C}} 57.3\right]$ and an aromatic proton $\left[\delta_{\mathrm{H}} 6.42(1 \mathrm{H}, \mathrm{s})\right]$.

Treatment of 1 with diazomethane gave a monomethyl ester (2) with the following physicochemical properties: oil; EIMS $m / z: 254\left(\mathrm{M}^{+}\right) ; \mathrm{UV} \lambda_{\max }(\mathrm{EtOH}) \mathrm{nm}(\hat{\varepsilon}): 203(11,900)$, 230 (sh, 7700), $278(4800)$; IR $v_{\max }(\mathrm{KBr}) \mathrm{cm}^{-1}: 3456,1744$, $1653,1613,1586,1516,1427,1363,1334,1276,1110$. The signals at $\delta_{\mathrm{II}} 5.60$ and 10.58 in the ${ }^{1} \mathrm{H}-\mathrm{NMR}$ spectrum of 2 (Table I) indicated the presence of phenolic and H-bonding phenolic hydroxyl groups, respectively. These results suggested that the structure of $\mathbf{1}$ was a pentasubstituted benzene derivative.

NOE difference and proton decoupling experiments on 1 suggested the order of the substituents. NOE was observed the signals at $\delta_{\mathrm{H}} 6.42$ and 3.64 , and in the

\begin{tabular}{|c|c|c|c|c|}
\hline \multirow{2}{*}{ Carbon number } & \multicolumn{2}{|c|}{1} & \multirow{2}{*}{$\frac{2}{\delta_{\mathrm{H}}}$} & \multirow{2}{*}{$\begin{array}{c}3 \\
\delta_{\mathrm{H}}\end{array}$} \\
\hline & $\delta_{\mathrm{C}}$ & $\delta_{\mathrm{H}}$ & & \\
\hline 1 & $176.5 \mathrm{~s}$ & & & \\
\hline 2 & $40.9 \mathrm{t}$ & $3.64 \mathrm{~s}$ & $3.89 \mathrm{~s}$ & $3.40 \mathrm{~s}$ \\
\hline 3 & $126.9 \mathrm{~s}$ & & & \\
\hline 4 & $108.5 \mathrm{~d}$ & $6.42 \mathrm{~s}$ & $6.41 \mathrm{~s}$ & 6.41 or $6.42 \mathrm{~d}(J=2.0 \mathrm{~Hz})$ \\
\hline 5 & $151.6 \mathrm{~s}$ & & & \\
\hline 6 & $134.9 \mathrm{~s}$ & & & \\
\hline 7 & $148.2 \mathrm{~s}$ & & & \\
\hline 8 & $123.6 \mathrm{~s}$ & & & 6.41 or $6.42 \mathrm{~d}(J=2.0 \mathrm{~Hz})$ \\
\hline 9 & $207.2 \mathrm{~s}$ & & & \\
\hline 10 & $33.1 \mathrm{q}$ & $2.55 \mathrm{~s}$ & $2.66 \mathrm{~s}$ & - \\
\hline 11 & $57.3 \mathrm{q}$ & $3.86 \mathrm{~s}$ & $3.97 \mathrm{~s}$ & $3.74 \mathrm{~s}$ \\
\hline$\left(-\mathrm{COOCH}_{3}\right)$ & & & $3.75 \mathrm{~s}$ & \\
\hline (free $-\mathrm{OH})$ & & & $5.60 \mathrm{br}$. & \\
\hline (H-bonding $-\mathrm{OH})$ & & & 10.58 br. & \\
\hline
\end{tabular}
proton decoupling experiments, irradiating the signals at

Table I. NMR DATA FOR 1 (IN $\left.\mathrm{CD}_{3} \mathrm{OD}\right), 2$ (IN $\mathrm{CD}_{3} \mathrm{Cl}$ ), AND 3 (IN $\mathrm{CD}_{3} \mathrm{COCD}_{3}$ ) 
Table II. LSPD EXPERIMENT ON 1

\begin{tabular}{cl}
\hline Proton $\left(\delta_{\mathrm{H}}\right)$ & \multicolumn{1}{c}{ Changed $\left(\delta_{\mathrm{C}}\right)$} \\
\hline 2.55 & $123.6,207.2$ \\
3.64 & $108.5,123.6,126.9,176.5$ \\
3.86 & 151.6 \\
6.42 & $108.5,123.6,126.9,134.9,151.6$ \\
\hline
\end{tabular}

Table III. EFFECTS OF 1, 2 AND 3 ON THE POLLEN Germination of Pinus thunbergii Part 1.

\begin{tabular}{|c|c|c|c|c|c|c|}
\hline \multirow{3}{*}{$\begin{array}{l}\text { Com- } \\
\text { pound }\end{array}$} & \multicolumn{6}{|c|}{ Pollen germination $(\%)^{a}$} \\
\hline & \multicolumn{6}{|c|}{ Conc. (mg/l) } \\
\hline & 1 & 3 & 10 & 30 & 100 & 300 \\
\hline 1 & 92.5 & 97.4 & 14.7 & 4.3 & 1.1 & 0.0 \\
\hline 2 & 103.3 & 98.5 & 99.0 & 99.1 & 6.1 & 0.0 \\
\hline 3 & 99.9 & 97.2 & 97.0 & 97.8 & $99: 3$ & 97.5 \\
\hline
\end{tabular}

a Germination is presented as the ratio to that of the control pollens.

$\delta_{\mathrm{H}} 6.42$ and 3.64 gave sharp signals at $\delta_{\mathrm{H}} 3.64$ and 6.42 , respectively. Further, NOE was observed between the signals at $\delta_{\mathrm{H}} 6.42$ and 3.86 . These results indicated relationships among a carboxymethyl, a aromatic proton and a methoxyl groups as shown in structure 1 .

Treatment of 1 with $50 \%$ sulphuric acid ${ }^{2)}$ gave a deacetyl compound (3) with the following physicochemical properties: mp 125-127 ${ }^{\circ} \mathrm{C}$; EIMS $m / z$ : $198\left(\mathrm{M}^{+}\right)$; UV $\lambda_{\max }$ $(\mathrm{EtOH}) \mathrm{nm}(\varepsilon): 212(2,000)$; IR $v_{\max }(\mathrm{KBr}) \mathrm{cm}^{-1}: 3475$, $1710,1620,1520,1425,1380,1230,1200,1110$. The
${ }^{1} \mathrm{H}-\mathrm{NMR}$ data are shown in Table I. The coupling constant $(J=2.0 \mathrm{~Hz})$ and chemical shifts of the aromatic protons in 3 suggested that the acetyl group of 1 was connected to the $\mathrm{C}-6$ or $\mathrm{C}-8$ position in 1 . However, long-range couplings between the $\mathrm{C}-10,-4$, and -2 protons and the C- 8 carbon $\left(\delta_{\mathrm{C}}: 123.6\right)$ indicated that the acetyl group of 1 was present in the ortho position of phenylacetic acid. The signal at $\delta_{\mathrm{C}}$ 134.9 was assigned to the $\mathrm{C}-6$ position by the long-range coupling with the $\mathrm{C}-4$ proton $\left(\delta_{\mathrm{H}}: 6.42\right)$. The LSPD experimental data for $\mathbf{1}$ are summarized in Table II. Therefore, the structure of 1 was determined to be 2acetyl-3,4-dihydroxy-5-methoxyphenyl-acetic acid.

1 is a new metabolite which differs from curvulic acid ${ }^{3\}}$ in the position of a hydroxyl and a methoxyl group, curvulic acid being known as an antimicrobial substance.

Vulculic acid (1) thus obtained from Penicillium sp. $(\mathrm{F}-25)$ and its derivatives ( 2 and $\mathbf{3}$ ) were assayed according to the method ${ }^{1)}$ described previously. Vulculic acid (1) showed the strongest activity and inhibited the pollen germination of Pinus thunbergii by $85.3 \%$ at a concentration of $10 \mathrm{mg} / 1.2$ at a concentration of $100 \mathrm{mg} / \mathrm{l}$ showed 93.9\% inhibitory activity, but 3 did not affect pollen germination at concentrations from $1 \mathrm{mg} / \mathrm{l}$ to $300 \mathrm{mg} / 1$. These observations suggest that an acetyl group played an important role in showing inhibitory activity, and a carboxymethyl group in the strength of the activity.

\section{References}

1) Y. Kimura, A. Shimada, H. Nakajima and T. Hamasaki, Agric. Biol. Chem., 52, 1253 (1988).

2) A. Kamal, A. Ali Qureshi and A. Ahmad, Tetrahedron, 21, 1411 (1965).

3) Y. Nakakita, S. Shima and H. Sakai, Agric. Biol. Chem., 48, 1899 (1984). 